\title{
Prediction of soil cover and soil rock for rangeland infiltration
}

\author{
WALTER J. RA WLS, DONALD L. BRAKENSIEK, J. ROGER SIMANTON, AND CLAYTON L. HANSON
}

Abstract

Lane et al. (1987) found that the proportion of bare or covered ground surface under the canopy is important for modeling infiltration in rangeland soils. Using a total of 322 composite plant canopy cover and ground cover measurements collected in Idaho, Arizona, and Nevada, equations were developed for predicting the ground cover under plant canopy from standard resource surveys or remote sensing techniques which primarily measure ground cover outside plant canopy. Equations were developed for predicting (1) percent by weight of soil rock in the top $76 \mathrm{~mm}$ of soil from ground cover measurements made outside of plant canopy, and (2) surface rock cover outside plant canopy from soil texture.

Key Words: remote sensing, surface rocks, canopy cover, water intake, soil texture

An important input to the management of rangelands is the ability to estimate the water intake properties of the soils. This is often complicated by coarse materials within the soil and variable soil surface covers that reflect long-term climate and land use patterns. A review by Brakensiek et al. (1986) indicated that coarse fragments in the soil reduce the saturated hydraulic conductivity. Mehan (1986) showed that rocks on the soil surface of rangelands tended to increase infiltration while rocks in the soil profile decreased the infiltration rate.

Lane et al. (1987) showed that vegetation canopy and soil surface cover of rangelands significantly influenced infiltration rates. They conducted infiltration tests on natural cover plots, plots with the canopy removed, and bare plots with canopy and most of the surface rock and litter removed. A comparison of the final infiltration rates showed a smaller final rate when the canopy was removed and a much smaller final rate when the surface rock and litter were also removed. It appears that as more soil surface is exposed, more of the soil surface develops a crust thus reducing infiltration rates.

Brakensiek and Rawls (1983) showed that a stable soil crust can reduce the saturated hydraulic conductivity by 75 to $90 \%$ of that observed on noncrusted soil. Therefore, it is important to know the amount of coarse fragments in the soil, canopy cover, and soil surface cover distribution. However, most rangeland soil cover surveys do not record ground cover under the plant canopy. Also, since most rangeland soils have not been mapped, the amount of coarse fragments in the soil is not known.

The purposes of this study were to develop predictive equations to estimate the amount of coarse fragments in rangeland soils and the amount of surface cover under canopy utilizing data normally collected in range resource surveys. Equations were developed for utilizing remote sensing data to make estimates of percent bare soil and rock cover outside of the canopy.

\section{Study Areas}

Idaho

Nine study sites were located on the USDA-ARS Reynolds

\footnotetext{
Authors are hydrologist, USDA-ARS Hydrology Laboratory, Beltsville, Maryland 20705; research associate, Department of Civil Engineering, University of Maryland, College Park, Maryland 20742; hydrologist, USDA-ARS Aridland Watershed Management Research Unit, Tucson, Arizona 85719; agricultural engineer, USDA-ARS Northwest Watershed Research Center, Boise, Idaho 83705.

Manuscript accepted 29 February 1988.
}

Creek Experimental Watershed in southwestern Idaho. Site elevations ranged from $1,200 \mathrm{~m}$ to higher than $2,100 \mathrm{~m}$ with the associated average annual precipitation ranging from 240 to $1,040 \mathrm{~mm}$, respectively. Precipitation occurs primarily during winter through early summer. Soils at the study site were derived from basalt, sediments, granite, or rhyolite; and soil textures vary from loam to gravelly loam (Stephenson 1977). The primary plant species is sagebrush (Artemisia tridentata) cover, except at one site where shadscale (Atriplex confertifolia) is the major brush species.

Soil cover and canopy cover were obtained from seven 100-point transects at each site. The point data were taken by the wheel-point method described by von Broembsen (1965). A wheel-point contacted the ground every $600 \mathrm{~mm}$ along the sampling transect. Hits were recorded from ground up when the spoke was vertical. There could be a basal hit plus 3 overstory hits. All ground level basal hits were considered basal cover. If the same species was hit more than once per point, only the first hit from the bottom was recorded. Plant hits with the wheel-point method were recorded when any part of the pin contacted a plant part. Two hundred and thirty-five transect measurements were made over an 8-year period (1971-1979). Average cover characteristics are given in Table 1 for the Idaho sites.

Table 1. Characteristics of cover measurements.

\begin{tabular}{|c|c|c|c|c|}
\hline & \multicolumn{4}{|c|}{ Percent of total area } \\
\hline & \multicolumn{2}{|c|}{$\begin{array}{c}\text { Idaho } \\
\mathbf{N}=235\end{array}$} & \multicolumn{2}{|c|}{$\begin{array}{c}\text { Arizona-Nevada } \\
\qquad \mathrm{N}=87\end{array}$} \\
\hline & Average & Range & Average & Range \\
\hline & & & & \\
\hline & 49 & $5-95$ & 63 & $10-92$ \\
\hline Under canopy & 51 & $5-95$ & 37 & $10-92$ \\
\hline \multicolumn{5}{|l|}{ Outside canopy } \\
\hline Bare & 17 & $0-60$ & 19 & $2-53$ \\
\hline Rocks' & 11 & $0-43$ & 37 & $3-49$ \\
\hline Litter & 21 & $0-63$ & 7 & $0-30$ \\
\hline \multicolumn{5}{|l|}{ Under canopy } \\
\hline Bare & 12 & $1-67$ & 15 & $2-62$ \\
\hline Rocks! & 4 & $0-41$ & 12 & $0-40$ \\
\hline Litter & 35 & $0-93$ & 10 & $0-22$ \\
\hline \multicolumn{5}{|l|}{ Canopy type } \\
\hline Grass & 25 & $0-90$ & 29 & $0-82$ \\
\hline Forbes & 14 & $0-61$ & 24 & $0-98$ \\
\hline Shrub & 61 & $2-89$ & 47 & $0-98$ \\
\hline
\end{tabular}

'Rocks were defined as $>\mathbf{2} \mathbf{m m}$ in diameter

\section{Arizona-Nevada}

Five sites used were located in southeastern Arizona and southern Nevada (Lane et al. 1987) (Table 1). Elevations of these sites ranged from 1,000 to $1,400 \mathrm{~m}$ and annual precipitation ranged from 160 to $320 \mathrm{~mm}$. The soils at the study areas ranged from gravelly loam to loamy sand with up to $50 \%$ coarse fragments (by volume) in the soils. The dominant plant types were grama (Bouteloua), grasses, and creosote bush (Larrea tridentata).

Soil surface cover and vegetation canopy cover were obtained with a point-frame meter with pins spaced every $60 \mathrm{~mm}$ of its $3 \mathrm{~m}$ length. Surface and canopy measurements were determined at 490 
points on the 3.05 by $10.7-\mathrm{m}$ plots. The characteristics measured at each point were: bare soil (particles $<2 \mathrm{~mm}$ ), gravel (particles 2-20 $\mathrm{mm}$ ), rock (particles $>20 \mathrm{~mm}$ ), litter, and vegetation basal and canopy cover. Eighty-seven measurements were made over a 5year period (1981-1985). Average cover characteristics are given in Table 1 for the Arizona-Nevada sites.

\section{Utah}

Thirty-five sites were located in central and southern Utah (Williams 1969). Elevations of the sites ranged from 1,800 to $2,400 \mathrm{~m}$ and annual precipitation ranged from 250 to $410 \mathrm{~mm}$. The soils were derived from colluvium, alluvium, residum, and eolian of mainly sedimentary and volcanic rocks and sandstones and shales. The dominant plant types were wheatgrass (Agropyron sp.). Soil cover and canopy cover were obtained with a 100-point quadrat frame which covered a $1,600-\mathrm{mm}^{2}$ area. At each site about 8 samples were taken for a total of 34 . Also, the \%sand, \%clay, and \%soil rock $>2 \mathrm{~mm}$ ) were measured for the top $76 \mathrm{~mm}$ soil profile. A summary of the Utah canopy and soil properties is given in Table 2.

Table 2. Characteristics of Utah soils and cover measurements'.

\begin{tabular}{lcc}
\hline \hline & Average (\%) & Range (\%) \\
\hline Sand $^{2}$ & 43 & $9-90$ \\
Clay $^{2}$ & 22 & $9-66$ \\
Open & 91 & $24-99$ \\
Canopy & 8 & $0-76$ \\
Surface rock $>2 \mathrm{~mm})$ & 15 & $0-95$ \\
Soil rock $>2 \mathrm{~mm})^{2}$ & 21 & $0-65$ \\
\hline
\end{tabular}

Sample size equals 34

${ }^{2}$ For the top $76 \mathrm{~mm}$

The primary difference between the Utah data and the Idaho, Arizona, and Nevada data is that the Utah data soil properties were measured but the soil cover under canopy was not.

\section{Results}

To estimate the percent of bare ground under the plant canopy where the surface cover outside of the plant canopy is known, using multiple regression techniques, a prediction equation was developed from the data obtained at the Idaho, Arizona, and Nevada sites, which are normally collected in range resource surveys. The equation is

$$
\begin{gathered}
\mathrm{UB}=-0.35-0.47(\mathrm{OB})+56.59(\mathrm{OBN})-0.57(\mathrm{OR})+46.21(\mathrm{ORN}) \\
r^{2}=.56, \mathrm{n}=322
\end{gathered}
$$

where

$\mathrm{UB}=\%$ area under canopy which is bare

$\mathrm{OB}=\%$ area outside canopy which is bare

$O C=\%$ area outside canopy

$\mathrm{OBN}=\mathrm{OB} / \mathrm{OC}$

$\mathrm{OR}=\%$ area outside canopy covered by rocks

$\mathrm{ORN}=\mathrm{OR} / \mathrm{OC}$

Since remote sensing is a proven cost effective alternative to manual resource surveys for obtaining plant canopy cover and the rock covered soil outside plant canopy cover based on the remotely sensed value of the area outside plant canopy cover. The equations are

$$
\begin{array}{ll}
\mathrm{OB}=2.63+.39(\mathrm{OC}) & r^{2}=.72, \mathrm{n}=322 \\
\mathrm{OR}=-8.98+.76(\mathrm{OC})-.76(\mathrm{OB}) & r^{2}=.85, \mathrm{n}=322
\end{array}
$$

Equation 3 can be used in conjunction with equation 2 to estimate the bare ground outside plant canopy cover, or an independent estimate of the bare ground outside plant canopy cover can be used. Also, the area outside of plant canopy cover which is covered with litter can be determined by subtracting the bare (OB) and rock (OR) covered surface outside plant canopy cover from the total area (OC) outside plant canopy cover.

It was thought that the amount of surface rocks should be dependent on the soil texture and the amount of rocks in the upper soil profile. If these soil properties were available then equation 3 estimates could be improved. Using the Utah data and regression techniques the following equation was developed:

$$
\mathrm{OR}=48.13-.37(\mathrm{C})-.66(\mathrm{OC})+.39(\mathrm{SR})-.42(\mathrm{OB}) r^{2}=.88, \mathrm{n}=34(4)
$$

where

$\mathrm{C}=\%$ clay in the upper $76 \mathrm{~mm}$ of the soil profile

$\mathrm{SR}=\%$ by weight of soil rock in the upper $76 \mathrm{~mm}$ of the soil profile

Since the amount of rocks in the upper soil profile have a significant effect on water intake rates (Brakensiek et al. 1986), we also developed from the Utah data an equation for predicting the \% by weight of soil rock in the upper $76 \mathrm{~mm}$ from surface soil cover conditions. The equation is

$$
\mathrm{SR}=-12.2+.4(\mathrm{OR})-.49(\mathrm{OB})+.61(\mathrm{OC}) \quad r^{2}=.86, \mathrm{n}=34
$$

The above equations were developed from a wide range of cover conditions (Tables 1 and 2); however, their use in predominately grass areas is questionable.

\section{Conclusions}

Previous studies have shown that plant cover canopy, ground cover, and rocks in the soil profile have a significant effect on infiltration rates. Based on available data from Idaho, Arizona, and Nevada, equations were developed to determine the soil surface cover conditions under plant canopy cover utilizing standard resource surveys or remote sensing techniques. An equation for predicting surface rock based on surface cover characteristics and/or soil texture is presented. Also, an equation to predict the \% by weight of soil rock in the upper $76 \mathrm{~mm}$ soil profile from the surface cover outside of plant canopy cover is presented.

\section{References}

Brakensiek, D.L., W.J. Rawls, and G.R. Stephenson. 1986. Determining the saturated hydraulic conductivity of a soil containing rock fragments. Soil Sci. Soc. Amer. J. 50:834-835.

Brakensiek, D.L., and W.J.Rawls. 1983. Agricultural management effects on soil properties, Part Il. Green-Ampt parameters for crusting soils. Trans. ASAE 26:1753-1757.

Lane, L.J., J.R. Simanton, T.E. Hakonson, and E.M. Romney. 1987. Large-plot infiltration studies in desert and semiarid rangeland areas of the southwestern USA. Proc. Int. Conf. on Infiltration Development and Application, Univ. of Hawaii, Honolulu, p. 365-377.

Mehan, D. 1986. Effects of coarse fragments on infiltration rates and Green and Ampt parameters. M.S. Thesis, Range Science Dep., Utah State Univ., Logan.

Stephenson, G.R. 1977. Soil-geology-vegetation inventories for Reynolds Creek Watershed. Idaho Agr. Exp. Sta. Misc. Ser. 42 p.

von Broembsen, H.H. 1965. A wheel-point apparatus for the survey and measurement of open and semi-open savannah vegetation. Proc. 9 th Int. Grassl. Cong., vol. 2, Sao Paulo, Brazil, p. 1345-1348.

Williams, G. 1969. Analysis of hydrologic, edaphic, and vegetation factors affecting infiltration and erosion on certain treated and untreated pinyon-juniper sites. Ph.D. Thesis, Range Science Dep., Utah State University, Logan. 